ZOOLOGIA 28 (2): 233-246, April, 2011

doi: $10.1590 /$ S1984-46702011000200013

\title{
New or little known demosponges (Porifera) from Espírito Santo coast and seamounts (Brazil)
}

\author{
Eduardo Hajdu ${ }^{1,2}$ \& Jessica N. Teixeira ${ }^{1}$
}

${ }^{1}$ Departamento de Invertebrados, Museu Nacional, Universidade Federal do Rio de Janeiro, Quinta da Boa Vista s/n, São Cristovão, 20940-040, Rio de Janeiro, RJ, Brazil. E-mail: jessica_nt1@hotmail.com

2 Corresponding author. E-mail: eduardo.hajdu@gmail.com

\begin{abstract}
Phorbas capixaba sp. nov. is described from $54 \mathrm{~m}$ depth off Guarapari, diagnosed by its two clear-cut categories of isochelae from Phorbas spp. known from the Western Tropical Atlantic. Four nomina nova are proposed for homonyms in Phorbas spp.: P. bergmontae nom. nov. for P. areolatus Bergquist \& Fromont, 1988, preoccupied by $P$. areolatus (Thiele, 1905); P. burtoni nom. nov. for $P$. arborescens sensu (Burton, 1956), preoccupied by $P$. arborescens (Ridley, 1884); P. hechteli nom. nov. for P. ramosus (Hechtel, 1983), preoccupied by P. ramosus (Lendenfeld, 1888; in part - composite species); P. tanitai nom. nov. for P. purpureus (Tanita, 1961), preoccupied by P. purpureus (Carter, 1886). Three little known species are redescribed: Aplysina alcicornis Pinheiro et al., 2007; Mycale (Aegogropila) escarlatei Hajdu et al., 1995 and Yucatania sphaeroidocladus (Hartman \& Hubbard, 1999). All three are new records for Espírito Santo. The first and the last of these are range extensions, while the other fills a distribution gap. A list of sponges hitherto recorded from off Espírito Santo state, with indication of the bibliographic source of the record is given in appendix. In total, 118 species were compiled from 23 publications.
\end{abstract}

KEY WORDS. Checklist; Hymedesmiidae; nomen novum; Phorbas capixaba sp. nov.; Program REVIZEE.

The coast of the state of Espírito Santo pertains to a transition zone where the Tropical Brazilian marine biota and its remarkable Caribbean affinity starts loosing its coral reef aspect (LABOREL 1967). Additionally, this is an area where a notable concentration of seamounts off the Brazilian coast is found, most of which in the Brazilian Exclusive Economic Zone. The understanding of marine sponge biodiversity patterns in this area is nonetheless, severely hampered by the lack of comprehensive taxonomic studies (HAJDU et al. 1996). An important contribution towards upgrading this knowledge began by the identification of the huge collections gathered by Program REVIZEE - Central 'SCORE' (Muricy et al. 2006) with 105 benthos oceanographic stations done off the state $(47,3 \%$ of the total), 65 of which with collections made by dredging (LAVRADO 2006). Unfortunately, the 295 morphotypes recognized are, in the majority of cases, only preliminarily identified and much remains to be done before these collections become truly known, so that biogeography of marine sponges in this transitional zone can be better understood.

The few taxonomic studies describing Espírito Santo state sponges are those of Boury-Esnault (1973, 1 species), Solé-Cava et al. (1981, 11), Hajdu et al. (1992, 1), Boury-Esnault et al. (1994, 1), Hajdu \& Desqueyroux-Faúndez $(1994,1)$, Rodriguez \& Muricy
$(2007,1)$ and Vieira et al. $(2010,3)$. In order to contribute with a reversion of this situation, this study describes a new species and redescribes a few poorly-known species collected off the state of Espírito Santo. In addition, a checklist of marine sponge records for Espírito Santo is given, with bibliographic sources indicated.

\section{MATERIAL AND METHODS}

The specimens studied here originate from the biological oceanographic campaigns of the Program Revizee Central 'SCORE' V and VI, which intended to map biological resources and determine sustainable catches in the central portion of the outer continental shelf and the upper slope of the Brazilian coast (100-500 $\mathrm{m}$ depth, between Cape São Tomé and Salvador; Lavrado 2006, Muricy et al. 2006, 2007). Many shallower stations were sampled also. Additional material stems from isolated collections made by diving or dredging on coastal localities, partly by JNT. Figure 1 shows all collecting stations from which specimens are reported herein. Animals were identified following standard procedures, using thick sections and dissociated spicules under light microscopy, and Scanning Electron Microscopy (JEOL 6390 LV). 


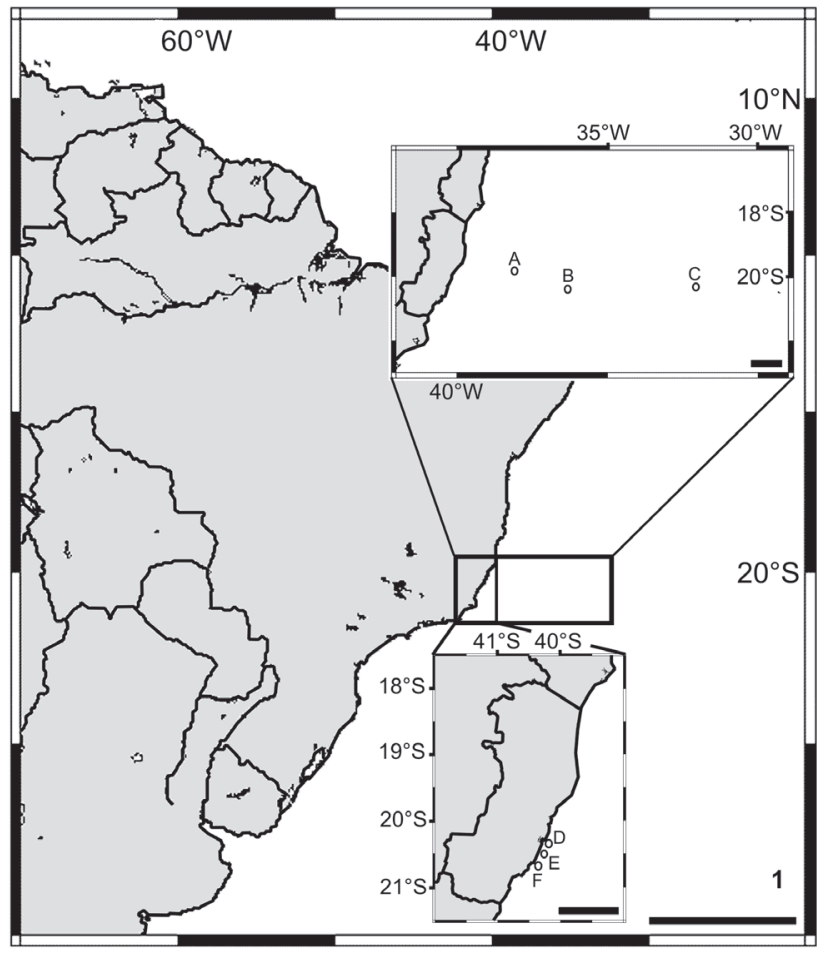

Figure 1. Map of the study area - sector of the western Atlantic with collecting stations off the coast of the state of Espírito Santo (A-C) and those closer to the coast (D-F). (A-C) Vitória-Trindade Seamounts Chain: (A) Eclaireur, (B) Jaseur seamount, (C) Columbia seamount, (D) Camburi, Vitória, (E) Ilha dos Pacotes, Vila Velha, (F) off Guarapari. Scales: Large map $=1000 \mathrm{~km}$, Inserts $=100 \mathrm{~km}$.

\section{TAXONOMY}

Porifera Grant, 1836

Demospongiae Sollas, 1885

Astrophorida Sollas, 1888

Thrombidae Sollas, 1888

Yucatania sphaeroidocladus

(Hartman \& Hubbard, 1999)

Figs 2-19, Tab. I

Diagnosis. The only Thrombidae with demotriaenes.

Description. The largest specimen available, still an obvious fragment, is MNRJ 4557. It is cushion shaped, $12 \times 9 \times 5$ $\mathrm{cm}$ (largest width, smallest width, thickness). Specimens can agglutinate abundant sediment (MNRJ 5872) and/or grow intermingled to abundant siliquariid gastropod shells (Siliquaria modesta; MNRJ 4557). Consistency of the sponge, where devoid of inclusions, is firm but compressible, somewhat friable. Texture is mostly rough also as a consequence of all the inclusions. Oscula were not seen, possibly due to the macerated condition of most samples. Colour alive (on deck) was reported as beige (MNRJ 4387D, 4562, 6192), white (MNRJ 4574) and lively yellow (MNRJ 5868B). Skeleton (Fig. 4). Confused architecture. Acanthodemotriaenes far outnumber acanthotriaenes. These spicules are densely packed both in the ectosome and choanosome, appearing at places to be somewhat juxtaposed in a palisade manner, while in other areas they are completely criss-crossing one another. Amphiasters were only spotted in dissociated spicules' mounts. Spicules (Tab. I). Megascleres.

Table I. Yucatania sphaeroidocladus: comparative table of spicule dimensions obtained from the literature and for the specimens described here. Values are in micrometers and are expressed as follows: smaller length or width - mean length or width - larger length or width. $\mathrm{N}$ $=25$ spicules. (n.r.) Not recorded.

\begin{tabular}{|c|c|c|c|}
\hline Specimens & Acanthodemotriaenes & Acanthotriaenes & Amphiasters \\
\hline & $\begin{array}{l}\text { rhabdome length/ } \\
\text { thickness/cladome width }\end{array}$ & $\begin{array}{l}\text { rhabdome length/thickness/ } \\
\text { cladome/cladi }\end{array}$ & \\
\hline MNRJ 4557 (ES, Brazil) & $\begin{array}{l}204-275.3-330 / \\
19-19.5-29 / 12-26.4-50\end{array}$ & $\begin{array}{l}41-60.2-79 / 7-10.4-12 / \\
24-36.9-53 / 10-21.4-29\end{array}$ & $6.3-7.6-8.8$ \\
\hline MNRJ 5872 (ES, Brazil) & $\begin{array}{l}223-287.4-398 / \\
10-11.7-29 / 12-21.8-36\end{array}$ & $\begin{array}{l}38-49.0-63 / 3-8.5-12 / \\
23-30.5-41 / 10-17.4-34\end{array}$ & $7-7.8-8.8$ \\
\hline $\begin{array}{l}\text { HARTMAN \& HUBBARD (1999; holotype, YPM } \\
\text { 9361), orig. descr. (Trinidad, Caribbean) as } \\
\text { Thrombus s. }\end{array}$ & $\begin{array}{l}296-416-480 / \\
12-23-30 / 10-14.6-20\end{array}$ & $\begin{array}{l}50-64-78 / 6.4-12.2-16 / \\
4-10.2-14 / 20-24.9-30\end{array}$ & $5.6-6.7-8$ \\
\hline $\begin{array}{l}\text { Gómez (2006; CNPGG 0735), orig. descr. } \\
\text { (Yucatán, México) as Y. clavus (holotype) }\end{array}$ & $\begin{array}{l}184-321-407 / \\
11-16-26 / \text { n.r. }\end{array}$ & $\begin{array}{l}33.8-57.5-78 / 6.5-8.9-11 / \\
\text { n.r./20.8-24.3-28 }\end{array}$ & $5-6-7$ \\
\hline $\begin{array}{l}\text { Gómez (2006; CNPGG 073), orig. descr. } \\
\text { (Yucatán, México) as Y. clavus (paratype) }\end{array}$ & $\begin{array}{l}200-312.8-405 / \\
10.5-15.5-21 / \text { n.r. }\end{array}$ & $\begin{array}{l}33-55.4-75 / 5.7-7.8-10.4 / \\
\text { n.r. } / 23-25.4-29\end{array}$ & $5-6-7$ \\
\hline MeneGola et al. (2009; BA, Brazil) & $\begin{array}{l}154-305-364 / \\
5-9-11 / 3-7-14\end{array}$ & $\begin{array}{l}39-61-90 / 2-6-11 / \\
2-5-9 / 18-20-29\end{array}$ & $6.0-6.1-7.7$ \\
\hline
\end{tabular}




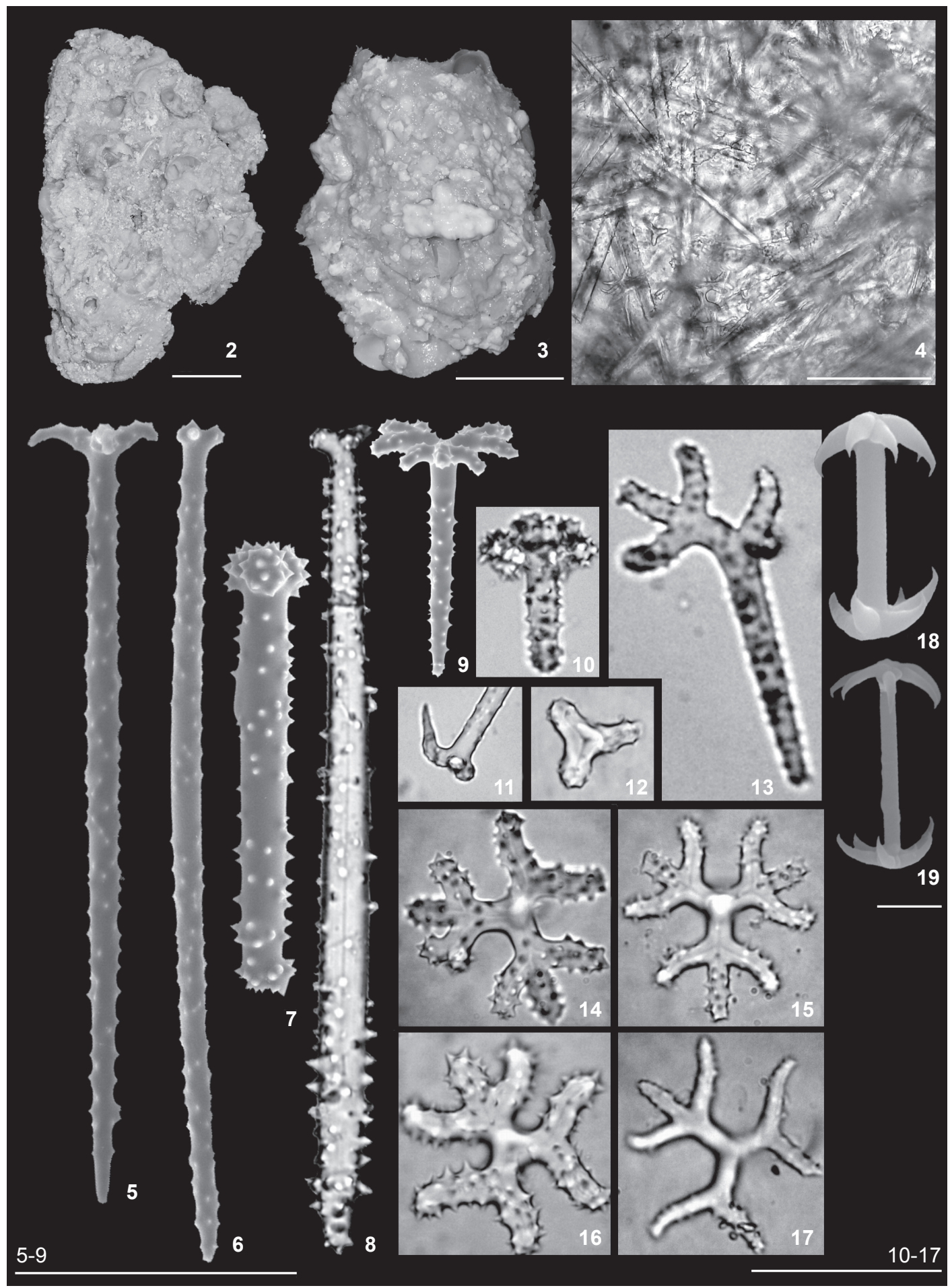

Figures 2-19. Yucatania sphaeroidocladus: (2) MNRJ 4557 in preserved state; (3) MNRJ 5852 in preserved state; (4) dense, confused architecture with acanthodemotriaenes and acanthotriaenes; (5-8, 11-12) acanthodemotriaenes; (10) spicule intermediary in shape between acanthodemotriaenes and acanthotriaenes; (9, 13-17) acanthotriaenes; (18-19) amphiasters. SEM: 5-7, 9, 18-19. Light microscopy: 4, 8, 10-17. Scales: $2-3=3 \mathrm{~cm} ; 4=1 \mathrm{~cm} ; 5-9=100 \mu \mathrm{m} ; 10-17=50 \mu \mathrm{m} ; 18-19=2 \mu \mathrm{m}$. 
Acanthodemotriaenes (Figs 5-8 and 11-12), with variable rhabdomes and cladomes. Rhabdomes can be long or short, robust or slender, fusiform or isodiametric, tapering to a moderately sharp end or markedly blunt, and bear abundant spines, usually small, but occasionally large as thorns. Cladomes, frequently just slightly wider than rhabdome thickness, usually bear tuberose, blunt clades, but occasionally one of these grows into plagio- or ana- forms, when they become slightly more slenderly terminated. Acanthotriaenes (Figs 9 and 13-17) with remarkably variable cladomes. These can be of the normal triaene form, as well as dicho- or tricho-, and such specializations may occur in one, two or all the clades. Spines are large and sharp, and distributed over most of the rhabdome and cladome. They are less common where the rhabdome approaches the cladome, and do not occur in the protoclads. Figure 10 shows a spicule of intermediate morphology between acanthodemotriaenes and acanthotriaenes. Microscleres. Amphiasters (Figs 18-19), with straight, smooth, variably thick shafts, and 5-6 sharp (spurred-)spines at each end, disposed in an umbrella-like fashion around the shaft.

Studied material. BraziL, Espírito Santo: Eclaireur Seamount (Vitória-Trindade Seamounts Chain, Program REVIZEE, R/V Astro Garoupa, Central V cruise, stn. \#30R, $20.151^{\circ} \mathrm{S}-37.480^{\circ} \mathrm{W}$, $60 \mathrm{~m}$ depth), 13/vii/2001, H.P. Lavrado leg., MNRJ 4387D. Columbia Seamount (Vitória-Trindade Seamounts Chain, Program REVIZEE, R/V Astro Garoupa, Central V cruise, stn. \#42R, $20.738^{\circ} \mathrm{S}, 31.828^{\circ} \mathrm{W}, 80-90 \mathrm{~m}$ depth), 11/vii/2001, H.P. Lavrado leg., MNRJ 4557, 4574, 5868B. 30 miles off Vitória (VitóriaTrindade Seamounts Chain, Program REVIZEE, R/V Astro Garoupa, Central V cruise, stn. \#34R, $20.402^{\circ} \mathrm{S}, 39.923^{\circ} \mathrm{W}, 50$ $\mathrm{m}$ depth), 15/vii/2001, H.P. Lavrado leg., MNRJ 4562. Jaseur Seamount (Vitória-Trindade Seamounts Chain, Program REVIZEE, R/V Astro Garoupa, Central V cruise, stn. \#23R, $20.487^{\circ} \mathrm{S}, 36.103^{\circ} \mathrm{W}, 50-60 \mathrm{~m}$ depth), 12/vii/2001, H.P. Lavrado leg., MNRJ 5872B. Off Guarapari (Vitória-Trindade Seamounts Chain, Program REVIZEE, R/V Astro Garoupa, Central VI cruise, stn. \#y4, $20.633^{\circ} \mathrm{S}, 40.025^{\circ} \mathrm{W}, 54 \mathrm{~m}$ depth), 14/vi/2002, H.P. Lavrado leg., MNRJ 6192.

Ecology and distribution. Specimens were dredged at moderate depth $(50-90 \mathrm{~m})$ from seamounts of the VitóriaTrindade chain and the continental shelf off Vitória. Sea-bottom in the area is mostly calcareous, and consisted of patches of rodoliths, rodoliths/sand and rodoliths/gravel. Specimen 5868 had epibiotic sertulariid hydrozoans Dynamena dalmasi (Versluys, 1899) (det. V. Shimabukuru \& A.C. Marques), while every specimen analyzed had endobiotic siliquariid gastropods (Siliquaria modesta Dall, 1881; det. A.D. Pimenta).

Remarks. The material from Espírito Santo studied here conforms in most characters to specimens previously described from Trinidad (type locality; HARTMAN \& HUbBARd 1999, as Thrombus sphaeroidocladus), the Yucatan Península, Mexico (Gómez 2006, as Y. clavus) and from Bahia, Brazil (Menegola et al. 2009). Not only spicule shape and dimensions conform in general but also the remarkable association to siliquariid gastropods is maintained over this rather large distance (ca. $8000 \mathrm{~km}$ ). A single exception to this near-perfect match is the mean length of rhabdomes found by Hartman \& Hubbard (1999) in the demotriaenes (as acanthotriaenes) of the type material - 405$416 \mu \mathrm{m}$, as opposed to $275-287 \mu \mathrm{m}$ found here, and 305-321 $\mu \mathrm{m}$ found elsewhere (Gómez 2006; Menegola et al. 2009). Given the similarity of all other aspects observed, this is considered of minor importance. HaRTMAN \& HubBaRd (1999) studied fragments from a very large sponge, said to cover more than $3 \mathrm{~m}^{2}$ in area. They remarked that species of Thrombus are apparently very rare as they are known from scattered records only. This may not hold true for Yucatania, dredged by the Program REVIZEE from three seamounts and two continental shelf locations, off Espírito Santo state. Albeit registered from neighboring areas in Bahia (Menegola et al. 2009), the species does not appear to be equally common there.

\section{Poecilosclerida Topsent, 1928 \\ Myxillina Hajdu, van Soest \& Hooper, 1994 Hymedesmiidae Topsent, 1928 \\ Phorbas capixaba sp. nov. Figs 20-30, Tab. II}

Holotype. BraziL, Espírito Santo: Off Guarapari (VitóriaTrindade Seamounts Chain, Program REVIZEE, R/V Astro Garoupa, Central VI cruise, stn. \#y4, $20.633^{\circ} \mathrm{S}-40.025^{\circ} \mathrm{W}, 54 \mathrm{~m}$ depth), 14/vi/2002, H.P. Lavrado leg., MNRJ 6176.

Diagnosis. This is the only Phorbas in the Tropical western Atlantic with two clear cut categories of arcuate isochelae.

Description. The single specimen is a small bush with two main, rather irregularly outlined branches, presumably previously attached to the substrate by a couple of short stolons about $1 \mathrm{~cm}$ long and $1 \mathrm{~cm}$ wide. The greatest diameter (ground projection) of the sponge is $7 \mathrm{~cm}$, and the largest branch is $4 \mathrm{~cm}$ long and up to $2 \mathrm{~cm}$ thick. Consistency is compressible and slightly elastic, and texture a bit rough due to the rather irregular outline of the branches, in part a consequence of embedded detritus. Surface is microconulose upon closer inspection. No areolated pore fields were recognized in the preserved specimen, which might be due to considerable damage to its surface having been inflicted by the dredging. Nevertheless, a thin transparent membrane can be seen at places, partially reticulated, and interrupted by a couple of small, inconspicuous oscula (1-2 $\mathrm{mm}$ in diameter). Color in life was reported as orange, which turned to beige in ethanol. Skeleton (Figs 2123). Ectosome with dense single layered crust of isochelae (Fig. 21). Uncommon, short subectosomal tracts of tornotes fan out underneath the surface, only slightly piercing it. The choanosome has a mainly plumose architecture, with sinuous, densely echinated tracts running towards the surface. These appear to be cored by foreign debris. Echinating acanthostyles 


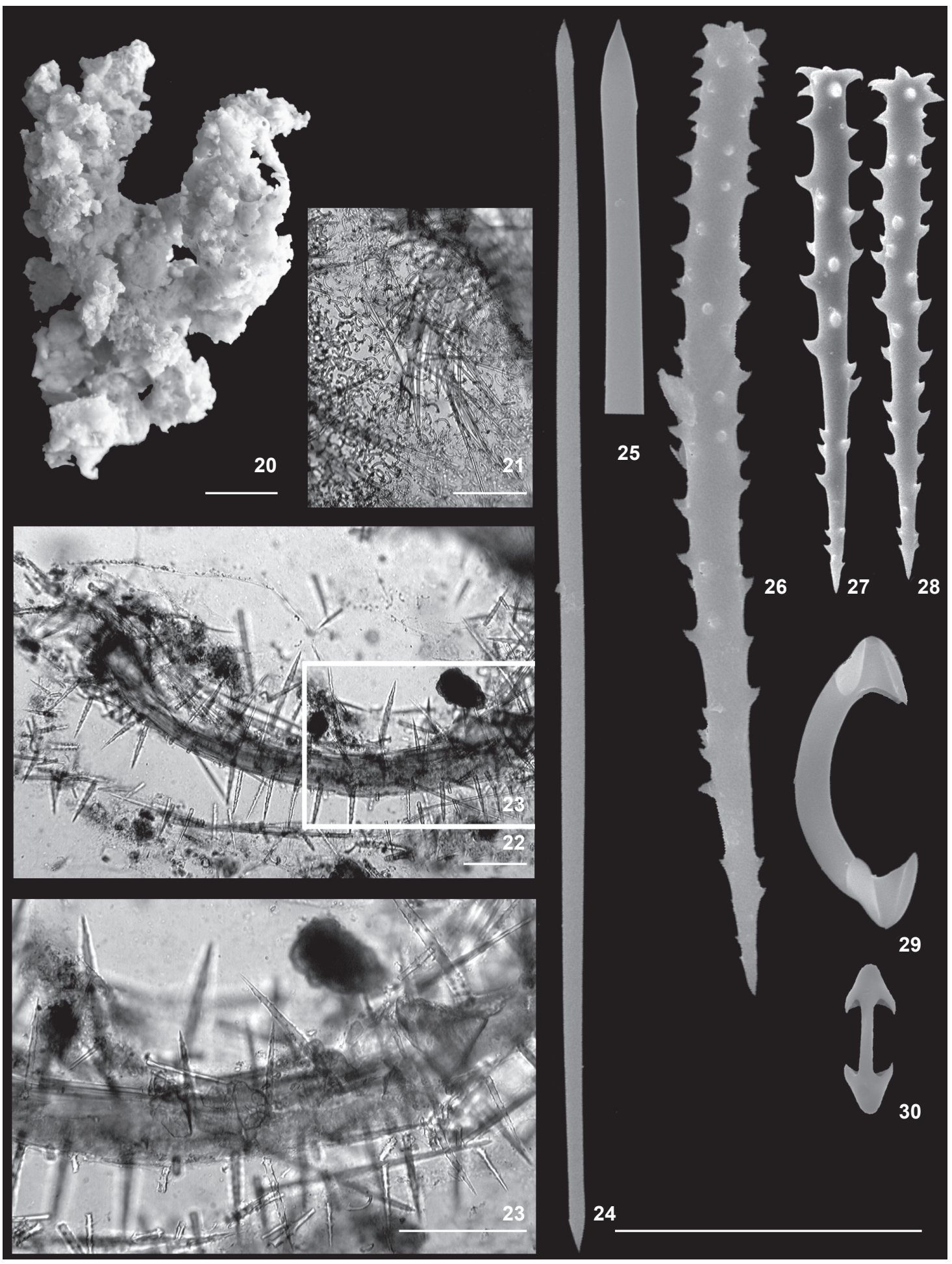

Figures 20-30. Phorbas capixaba sp. nov., holotype, MNRJ 6176: (20) preserved specimen; (21) detail of ectosomal crust of isochelae; (22) equinated choanosomal tract; (23) choanosomal tract cored by debris; (24) tornote; (25) detail of tornote extremity; (26) acanthostyle I; (27-28) acanthostyles II; (29) isochelae I; (30) isochelae II. Scales: $20=1 \mathrm{~cm}, 21-23=100 \mu \mathrm{m}, 24,26-28=50 \mu \mathrm{m} ; 25,29-30=25 \mu \mathrm{m}$. 
Table II. Comparative table of spicule dimensions of Tropical western Atlantic Phorbas. Values are in micrometers and are expressed as follows: smaller length - mean - larger length/smaller width - mean - larger width ( $\mathrm{N}$, when distinct from 25 spicules). (n.r.) Not recorded.

\begin{tabular}{|c|c|c|c|}
\hline Species & Tornotes & Acanthostyles & Isochelae \\
\hline P. capixaba sp. nov., holotype & $182-198.1-214(27) / 7$ । & $\begin{array}{l}\text { I, } 63-75.3-87 / 5-8.1-10(46) \\
\text { II, } 103-158.1-240 / 10-11.3-14(54)\end{array}$ & $\begin{array}{l}\text { I, } 24-26.1-31(27) \\
\text { II, } 12-13.9-17(27)\end{array}$ \\
\hline $\begin{array}{l}\text { P. amaranthus Duchassaing \& Michelotti, } \\
\text { 1864; sensu VAN SOEst (1984) }\end{array}$ & $\begin{array}{l}235-254.4-266 / \\
3.5-4.4-5.5\end{array}$ & $\begin{array}{l}\text { I, } 91-104.3-112 / 4.5-6.0-7.5 \\
\text { II, } 129-159.4-182 / 5-6.6-7.5\end{array}$ & $\begin{array}{l}\text { I, } 20-22.1-24 \\
\text { II, n.r. }\end{array}$ \\
\hline $\begin{array}{l}\text { P. hechteli nom. nov. [P. ramosus (Hechtel, } \\
\text { 1983; as Anchinoe r.)], orig. descr. }\end{array}$ & $\begin{array}{l}138-166.8-188 / \\
1.5-1.8-3\end{array}$ & $\begin{array}{l}\text { I, } 49-68.5-115 / 3.5-3.9-6 \\
\text { II, n.r. }\end{array}$ & $\begin{array}{l}\text { I, } 18-21.4-23 \\
\text { II, n.r. }\end{array}$ \\
\hline $\begin{array}{l}\text { P. fusifer (Ridley \& Dendy, 1887; as } M \text {. } \\
\text { plumosa var. fusifer), orig. descr. }\end{array}$ & $175 / 4.8$ & $\begin{array}{l}\text { I, } 100-160 / 8-13 \\
\text { II, n.r. }\end{array}$ & $\begin{array}{l}\text { I, } 15-20 \\
\text { II, n.r. }\end{array}$ \\
\hline
\end{tabular}

are placed rather regularly, each located 25-50 $\mu \mathrm{m}$ away from its closest neighbors, rendering the tracts a polychaete-like aspect (Figs 22 and 23). Spicules (Tab. II, Figs 24-30). Megascleres. Ectosomal tornotes, slightly fusiform, straight or slightly sinuous, terminations slightly lanceolated (Figs 24 and 25). Acanthostyles I, more heavily spined in the basal half, spines mostly slightly curved toward the base, but for the basal 1/6-1/ 7 where they point to the apex slightly, basalmost spines frequently blunt (Fig. 26). Acanthostyles II (Figs 27 and 28), nearly equally spined all over, with spine orientation similar to that of acanthostyles I. Microscleres. Arcuate isochelae 1, stout axis and poorly developed alae (ca. 25\% the total height; Fig. 29). Arcuate isochelae 2, slender axis, more developed alae (ca. 33\% the total height; Fig. 30).

Ecology and Distribution: So far known only from the type locality, the south-eastern Brazilian continental shelf off Guarapari, at $54 \mathrm{~m}$ depth. The species was dredged from calcareous bottoms.

Etymology. The species name is a noun in apposition referring to the people born in Espírito Santo State, the 'capixabas'.

Remarks. There are 76 species listed for Phorbas in the World Porifera Database (van Soest et al. 2009), only three of which are known from Brazil (Tab. II): P. amaranthus Duchassaing \& Michelotti, 1864; P. fusifer (Ridley \& Dendy, 1887) and P. hechteli [new name for P. ramosus (Hechtel, 1983; as Anchinoe ramosus), preoccupied by $P$. ramosus (Lendenfeld, 1888; as Echinonema ramosum)]. The new species clearly differs from all, as argued below. Phorbas amaranthus, according to VAN SOEST (1984), has larger tornotes and a single category of isochelae, intermediate in size between both categories here reported for the new species. Furthermore, its tornotes and acanthostyles are rather slender. Phorbas fusifer, as originally described, possesses smaller and slender tornotes, a single category of acanthostyles of intermediate dimensions, and a single category of isochelae, also intermediate between both categories occurring in the new species. Finally, Phorbas hechteli new name bears considerably thinner megascleres, where acanthostyles belong in a single size category. Once again, isochelae occur in a single category, intermediate in size to those of $P$. capixaba sp. nov. No further species of Phorbas is known from the Tropical western Atlantic, so the new species is here considered well differentiated from its congeners inhabiting the biogeographic region it pertains to. By analyzing the list of species in VAN SOEST et al. (2009) it became apparent that homonymy is a remarkable problem in Phorbas. Apart from the above-mentioned case, another three pairs of homonymous species exist, viz. Phorbas arborescens (Ridley, 1884; as Myxilla arborescens) and $P$. arborescens (Burton, 1956; as Hymedesmia arborescens), P. areolatus (Thiele, 1905; as Hymedesmia areolata) and $P$. areolatus Bergquist \& Fromont, 1988, and $P$. purpureus (Carter, 1886; as Plumohalichondria purpurea) and $P$. purpureus (Tanita, 1961; as Anchinoe purpurea). Nomina nova are proposed here for all three cases pointed above, as follows. For clarity sake, $P$. hechteli nom. nov. is also repeated below.

\section{Nomina nova}

Phorbas bergmontae nom. nov. for Phorbas areolatus Bergquist $\&$ Fromont, 1988, type species $P$. areolata, from North Cape, New Zealand, preoccupied by P. areolatus (Thiele, 1905), type species Hymedesmia areolata, from Calbuco, Chile.

Phorbas burtoni nom. nov. for P. arborescens sensu Burton, 1956; type species Hymedesmia arborescens, from Guinea, $9^{\circ} 20^{\prime} \mathrm{N}$, $14^{\circ} 15^{\prime} \mathrm{W}$, West Africa, preoccupied by P. arborescens (Ridley, 1884), type species Myxilla arborescens from Port Jackson, SE Australia.

Phorbas hechteli nom. nov. for P. ramosus (Hechtel, 1983), type species Anchinoe ramosus from Bahia, Brazil, preoccupied by P. ramosus (Lendenfeld, 1888), type species Echinonema ramosum from SE Australia; in part - composite species.

Phorbas tanitai nom. nov. for Phorbas purpureus (Tanita, 1961), type species Anchinoe purpurea from Japan, preoccupied by P. purpureus (Carter, 1886), type species Plumohalichondria purpurea from Westernport Bay (SE Australia) and Maria Island (Tasmania, Australia). 


\author{
Mycalina Hajdu, van Soest \& Hooper, 1994 \\ Mycalidae Lundbeck, 1905 \\ Mycale (Aegogropila) Gray, 1867 \\ Mycale (Aegogropila) escarlatei \\ Hajdu, Kielman, Zea \& Peixinho, 1995
}

Figs 31-41, Tab. III

Diagnosis. Only Mycale with "duck's bill"-like anisochelae in the Atlantic Ocean.

Description. The collected specimen consisted of two small fragments, each $<1 \mathrm{~cm}$ in maximum diameter and ca. 1 $\mathrm{mm}$ thick. Virtually nothing remains apart from the preparations used to base this description. Their surface was slightly hispid. No oscules were apparent. Color in the preserved state was beige. Skeleton (Fig. 31). Ectosomal architecture an isotropic triangular reticulation formed by multispicular tracts of mycalostyles (4-8 spicules across). Meshes are 150-200 $\mu \mathrm{m}$ in diameter. Anisochelae I are organized in abundant rosettes, attached to the multispicular tracts at random, where a few sigmas I can also be found. Abundant anisochelae IV and rather fewer anisochelae II and sigmas II occur right in the middle of the meshes, side by side with pores $(20-80 \mu \mathrm{m}$ in diameter). Spicules (Tab. III, Figs 32-41). Megascleres. Mycalostyles (Fig. 32). Microscleres. Anisochelae I (Fig. 33 and 34), head about $50 \%$ total spicule height, large frontal alae slightly bent forward. Anisochelae II (Fig. 35), 'duck's bill'-like, head about 75\% total spicule height, large frontal alae pending down parallel to the axis. Anisochelae IV (Fig. 36), head about 70\% total spicule height, both frontal alae markedly spurred apically, and nearly overpassing each other. Sigmas I (Fig. 37), smooth, stout, contorted, uncommon. Sigmas II (Fig. 38), smooth, slender, contorted, common. Toxas (Figs 39 and 40), rare, smooth, variably curved (only three seen). Micracanthoxeas (Fig. 41), straight, heavily spined (sanidaster-like, only one seen).

Studied material: BraziL, Espírito Santo: Vitória (Camburi, ca. $20^{\circ} 17^{\prime} 18^{\prime \prime} \mathrm{S}, 40^{\circ} 15^{\prime} 60^{\prime \prime} \mathrm{W}$, field code CA $15 \mathrm{~A}$ ), no further collection data (probably collected on the 1980's or 1990's), MNRJ 2453.

Comparative material: UFRJPOR 4451 (holotype, Bomfim Island, Angra dos Reis, Rio de Janeiro State, Brazil).

Remarks. The dimensions of the studied material precluded any deeper search for additional toxas and micracanthoxeas. For most characters, the Espírito Santo material reported here matches closely the micrometric and micromorphologic data presented in the original description of the species (HAjDu et al. 1995). Nevertheless, data presented by Muricy \& HajDu (2006) deviate quite substantially, especially as far as sigmas I, toxas and micracanthoxeas are concerned, all reaching quite larger dimensions (respectively, 105, 140 and $9 \mu \mathrm{m}$ ). As the only additional material studied by MuRICY \& Hajdu (2006) in contrast to HAjDu et al. (1995) was the São Paulo State (Ilhabela) specimen(s), these appear to be in need of a thorough revision.
Verongida Bergquist, 1978

Aplysinidae Carter, 1875

\section{Aplysina alcicornis \\ Pinheiro, Hajdu \& Custódio, 2007 \\ Figs 42-46, Tab. IV}

Diagnosis. This is the only Aplysina in the Tropical western Atlantic with a flat lamellar body, relatively long, slender, irregularly digitiform fistules coloured as the sponge, and turning to a dark shade of brown in ethanol.

Description (Fig. 42-43). The single specimen is small, lamellate, ca. $8 \mathrm{~cm}$ high, $10 \mathrm{~cm}$ wide and $1 \mathrm{~cm}$ thick. Its apical portion is irregularly outlined, with short - lobate projections (ca. 1-2 cm high) wherefrom fistules arise. Up to three fistules were seen originating from a single lobate projection. A few, thick, irregular digitiform processes are seen, either aligned to the main lamella (ca. $8 \mathrm{~cm}$ high), or projecting from its side (ca. $2 \mathrm{~cm}$ high). The former bear apical fistules, while the latter do not. Surface is smooth, with a few oscules scattered on the apical portion of the lamella, 3-4 $\mathrm{mm}$ in diameter. Consistency was compressible, flexible. Live colour was homogeneously bright yellow (light coloured). Skeleton. A polygonal reticulation (Fig. 44) of spongin fibers (Figs 45 and 46) forming mostly three dimensional meshes of complex perimeter. Meshes are mostly broken up, but appear to be constrained between 400 and $1400 \mu \mathrm{m}$ in diameter.

Studied material. BrazIL, Espírito Santo: off Vila Velha (Ilha dos Pacotes, $20^{\circ} 21^{\prime} 04.00^{\prime \prime}$ S, $40^{\circ} 15^{\prime} 04.25^{\prime \prime} \mathrm{W}, 20 \mathrm{~m}$ depth), 02/ iv/2010, J.N. Teixeira leg., MNRJ 14048.

Comparative material. BrazIL, Bahia: Parque Nacional Marinho dos Abrolhos, MNRJ 5473 (holotype), 5472, 5474 (paratypes).

Ecology and distribution. The specimen was collected on rocky substrate, with an angle of about $60^{\circ}$, exposed to direct illumination. It had an epibiotic crinoid and many orange ophiuroids (Ophiotela danae, det. C.R.R. Ventura).

Remarks. Aplysina alcicornis is known from a single, recent description from the Abrolhos area (state of Bahia; PinHeIro et al. 2007). This specimen was darker in color and its fistules could bifurcate. We do not judge the divergence observed in these characters when contrasting Bahia and Espírito Santo materials, sufficient to recognize yet another species in Aplysina, especially because so few specimens are available for study still. Similar color morphs occur in A. fistularis and A. fulva. The material described here brings new information, as this is the first time where a full specimen was photographed in situ. PINHEIRO et al. (2007) pointed out that anatomical (fiber) characters are quite inconclusive as diagnostic features. The fibers of the specimen studied here are slightly thinner than those reported from Bahia, albeit with thicker piths. These do not appear to be clear-cut diagnostic features, but a further analysis will be in order when additional $A$. alcicornis - like specimens are available. 


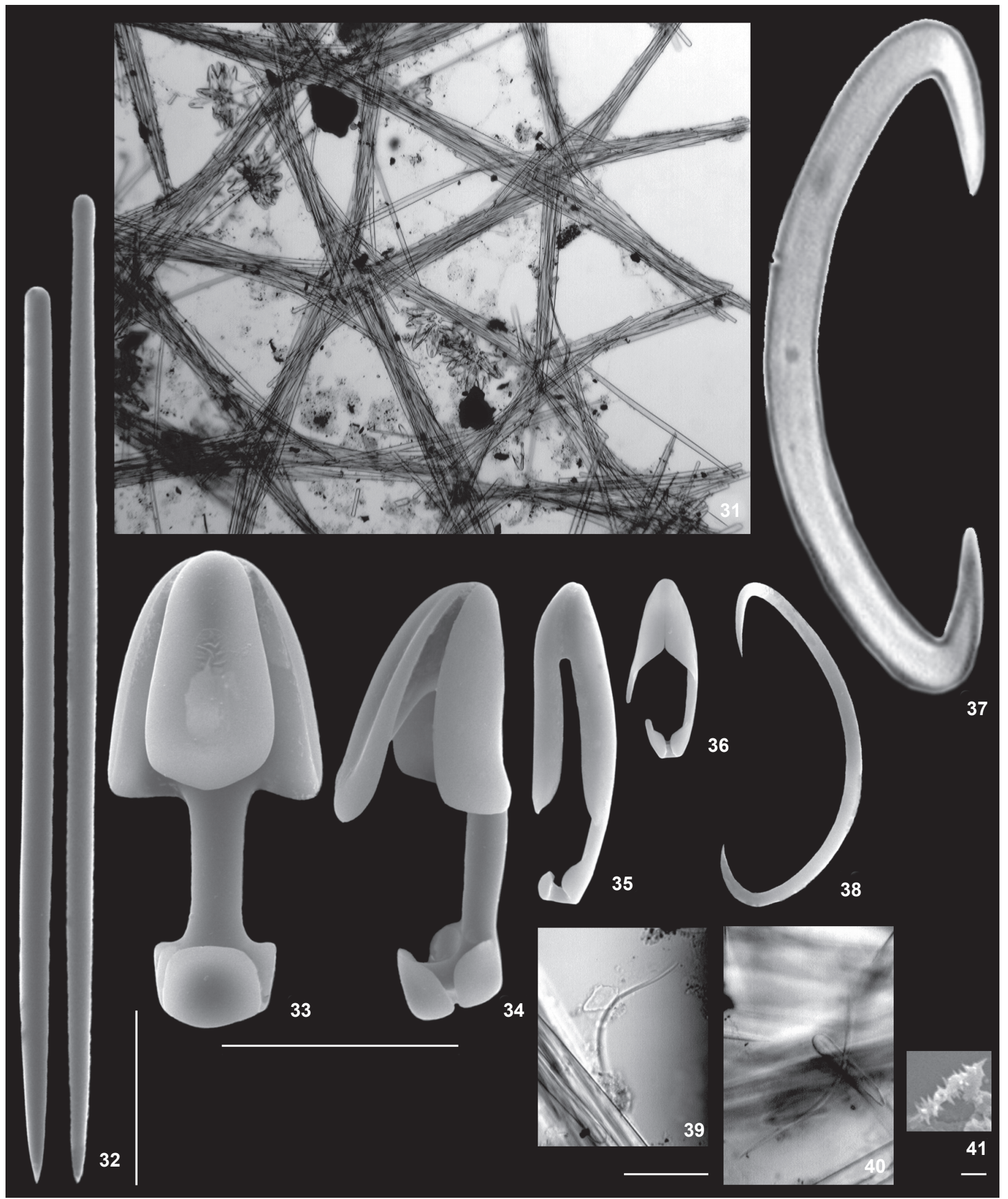

Figure 31-41. Mycale (Aegogropila) escarlatei, MNRJ 2453: (31) ectosomal architecture; (32) mycalostyles; (33) anisochelae I, frontal view; (34) anisochelae I, side view; (35) anisochelae II, 'duck's bill', side view; (36) anisochelae IV, side view; (37) sigma I; (38) sigma II; (39-40) toxas; (41) micracanthoxea. Scales: $31=150 \mu \mathrm{m}, 32=50 \mu \mathrm{m}, 33-40=20 \mu \mathrm{m}, 41=1 \mu \mathrm{m}$. 
Table III. Comparative table of spicule dimensions of published records of Mycale (Aegogropila) escarlatei type series, contrasted to those observed here for the Espírito Santo specimen. Values are in micrometers and are expressed as follows: smaller length - mean - larger length/smaller width - mean - larger width ( $N$, when distinct from 20 spicules). (n.f.) Not found.

\begin{tabular}{|c|c|c|c|c|c|}
\hline Species & Mycalostyles & Anisochelae & Sigmas & Toxas & Micracanthoxeas \\
\hline MNRJ 2453 (Camburi, ES) & $\begin{array}{l}243-280.8-310 / \\
2.9-8.6-10.7\end{array}$ & $\begin{array}{l}\text { I, } 34-39.4-45 \\
\text { II, } 24-29.4-38 \\
\text { III, } 12-12.7-15\end{array}$ & $\begin{array}{l}\text { I, } 50-60.5-70(10) \\
\text { II, } 22-27.2-38\end{array}$ & $\begin{array}{l}\text { I, } 41-45.6-60 \\
\text { (3) }\end{array}$ & $3.3(1)$ \\
\hline $\begin{array}{l}\text { HAJDU et al. (1995; holotype, } \\
\text { UFRJPOR 4451), orig. descr. (RJ, } \\
\text { Brazil) }\end{array}$ & $\begin{array}{l}254-318.3-350 / \\
8-9.2-11\end{array}$ & $\begin{array}{l}\text { I, } 34-42.8-46 \\
\text { II, } 24-29.5-32 \\
\text { IV, } 13-13.5-14\end{array}$ & $\begin{array}{l}\text { I, } 63-70.2-77 \\
\text { II, } 20-27-31\end{array}$ & $\begin{array}{l}\text { I, } 74-77 \\
\text { II, } 9-15.9-22\end{array}$ & $3-4$ \\
\hline $\begin{array}{l}\text { HAJDU et al. (1995; paratype MCN } \\
2829) \text {, orig. descr. (BA, Brazil) }\end{array}$ & $\begin{array}{l}249-275.1-292 / \\
4-6.9-8\end{array}$ & $\begin{array}{l}\text { I, } 35-38.3-42 \\
\text { II, } 28-29.5-32 \\
\text { IV, } 11-11.3-13\end{array}$ & $\begin{array}{l}\text { I, } 65-67.7-70 \\
\text { II, } 33-36.2-39\end{array}$ & $\begin{array}{l}\text { I, } 55-61.4-69 \\
\text { II, } 15-17.4-20\end{array}$ & n. f. \\
\hline $\begin{array}{l}\text { HAJDU et al. (1995; paratype INV } \\
\text { POR 448), orig. descr. (Punta de } \\
\text { Betin, Colombia) }\end{array}$ & $\begin{array}{l}271-286.9-309 / \\
3-6-11\end{array}$ & $\begin{array}{l}\text { I, } 35-38-41 \\
\text { II, } 25-29.2-33 \\
\text { IV, } 11-12.7-14\end{array}$ & $\begin{array}{l}\text { I, } 61-66.4-75 \\
\text { II, } 25-27.9-30\end{array}$ & $\begin{array}{l}\text { I, } 60-70.7-86 \\
\text { II, } 6-11.2-18\end{array}$ & n. f. \\
\hline $\begin{array}{l}\text { HAJDU et al. (1995; paratype INV } \\
\text { POR 449), orig. descr. (El Morro, } \\
\text { Colombia) }\end{array}$ & $\begin{array}{l}266-307.8-342 / \\
4-7.5-10\end{array}$ & $\begin{array}{l}\text { I, } 37-39.3-43 \\
\text { II, } 28-29.6-32 \\
\text { IV, } 11-13.8\end{array}$ & $\begin{array}{l}\text { I, } 57-65.3-73 \\
\text { II, } 27-30\end{array}$ & $\begin{array}{l}\text { I, } 71-92 \\
\text { II, } 15-23\end{array}$ & $3-3.4-4$ \\
\hline
\end{tabular}

Table IV. Comparative table of spongin fibers' dimensions of Aplysina alcicornis type series, contrasted to those observed here for the Espírito Santo specimen. Values are in micrometers, expressed as follows: smaller width - mean - larger width.

\begin{tabular}{lcc}
\multicolumn{1}{c}{ Specimens } & Whole fibers & Piths \\
\hline Present study, MNRJ 14048 (Ilha dos Pacotes, ES) & $31-71.7-109$ & $14-38.5-60$ \\
PINHEIRO et al. (2007), MNRJ 5473 (Holotype Abrolhos, BA) & $50-96.1-143$ & $15-32.1-83$ \\
MNRJ 5472 (Paratype Abrolhos, BA) & $57-97.3-140$ & $15-25.5-68$ \\
MNRJ 5474 (Paratype Abrolhos, BA) & $40-82.6-108$ & $15-25.8-35$ \\
\hline
\end{tabular}

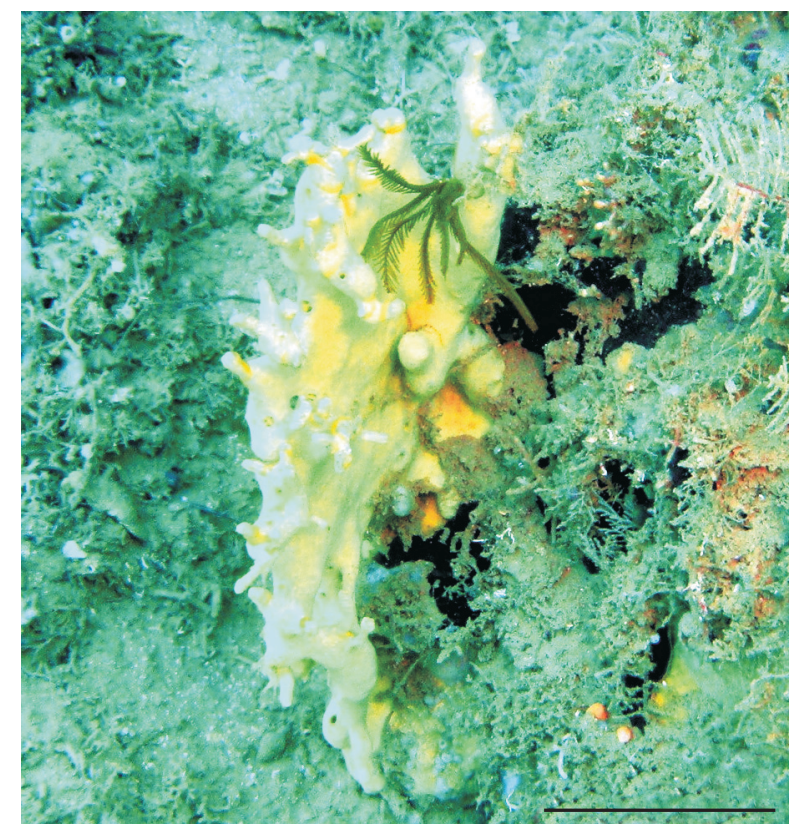

Figure 42. Underwater photograph of Aplysina alcicornis, MNRJ 14048. Scale: $5 \mathrm{~cm}$.

\section{DISCUSSION}

The list of sponges from the state of Espírito Santo comprises now over 110 species, compiled from 23 publications (Appendix). Species reported from the Almirante Saldanha seamount were compiled here also. A large proportion of these species are known also from areas to the north of the state, and many frequently reach the Caribbean Sea, suggesting to a Tropical-western Atlantic affinity of the sponge fauna in this alleged biogeographic transition zone (Solé-CAVA et al. 1981, Palacio 1982). For example, 31 out of 47 fully-identified Demospongiae have known geographic ranges stretching all the way to the Central West Atlantic (see Appendix).

Among the remaining 62 species reported, 46 are identified only to the generic level (as "sp.", "cf. sp. X" or "aff. sp. $\mathrm{X}^{\prime \prime}$ ) and may prove to be conspecific to known Caribbean sponges or strengthen the group of provisional Brazilian endemics. The number of provisional endemic Brazilian demosponges described from the coast of the state of Espírito Santo is 15 , including six provisional local endemic species Cinachyra helena Rodriguez \& Muricy, 2007; Erylus almirante Vieira et al., 2010; E. fluminense Vieira et al., 2010; E. revizee Vieira et al., 2010; Jaspis salvadori Boury-Esnault, 1973 and 


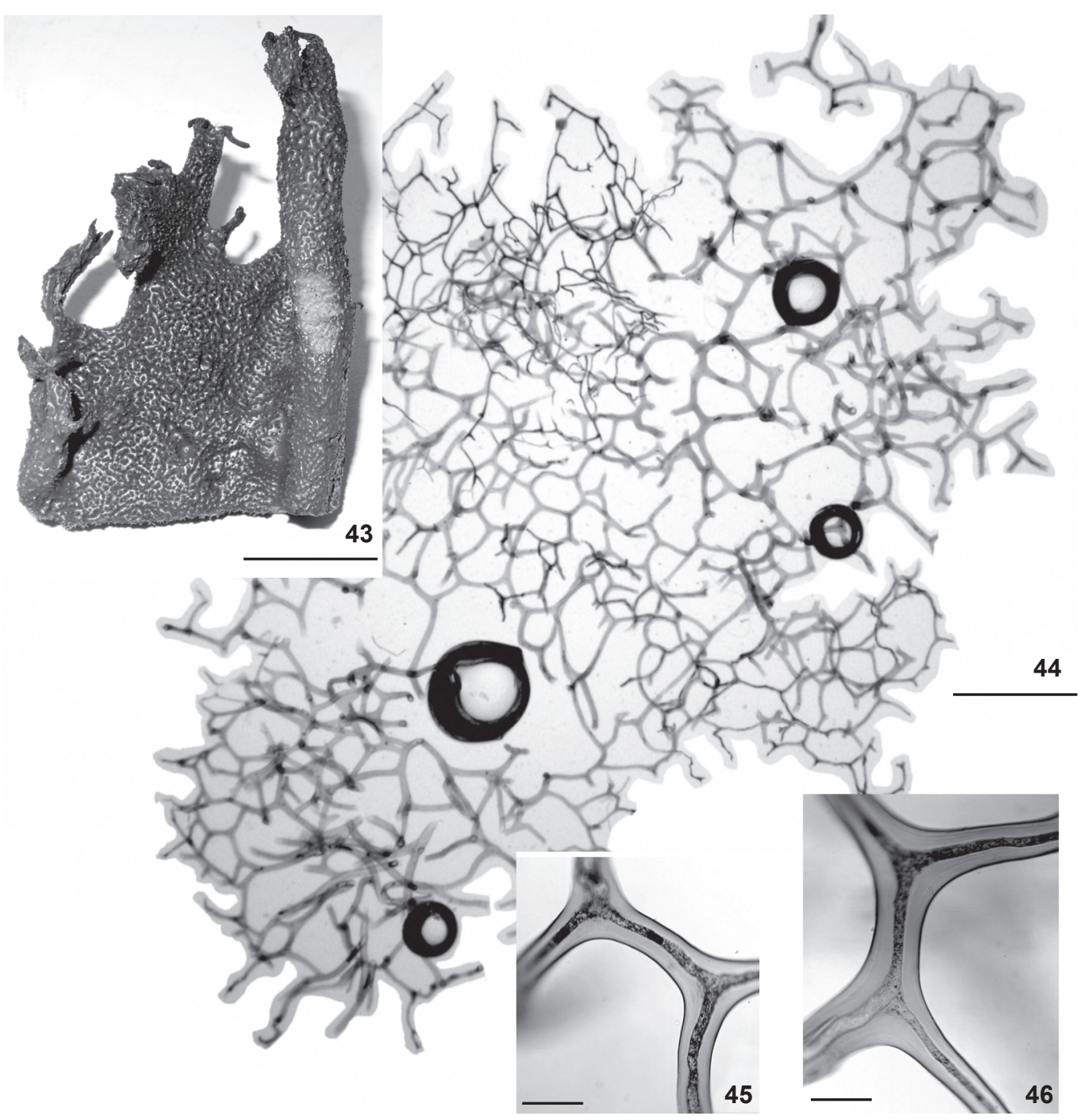

Figure 43-46. Aplysina alcicornis, MNRJ 14048: (43) preserved specimen; (44) cross section of architecture showing thinner fibres in the periphery; (45-46) detail of fibres with clearly visible bark (outer and clearer) and pith (inner and darker). Scales: $43=2 \mathrm{~cm} ; 44=2 \mathrm{~mm}$; $45-46=100 \mu \mathrm{m}$.

Phorbas capixaba sp. nov. The 13 Hexactinellida present another three provisional endemic species - Hyalonema conqueror Tabachnick et al., 2009; Hyalonema dufresnei Tabachnick et al., 2009 and Lophocalyx brasiliensis Menshenina et al., 2007. Of the 12 Calcarea reported herein, three are provisional endemics - Paraleucilla sp. (referred as 'sp. nov.' in Moraes et al. 2006); Sycettusa pelagica (Ridley, 1881) and Vosmaeropsis sericatum (Ridley, 1881). The latter two are also provisional endemics from the state of Espírito Santo.

Only two species are provisional disjunct records from non-adjacent areas, both in need of detailed morphologic comparisons with topotypical specimens - Dysidea avara (Schmidt, 1862) and Timea cumana Pulitzer-Finali, 1977.
The MNRJ and UFRJPOR collections together hold over 1000 sponge samples originating from the coast of the state of Espírito Santo, which are bound to reveal important answers to questions related to marine sponge biodiversity in this biogeographic transitional zone. An important research venue regards the level of population connectivity along the line of stepping-stones represented by the seamounts stretching from the border of the continental shelf off Vitória, to Trindade Island and the Archipelago of Martim Vaz, ca. $1160 \mathrm{~km}$ to the east. This issue might be studied through a comprehensive evaluation of genetic homogeneity (percentage of haplotypes) and distances between distinct populations of the same species, occurring along this latitude. Data presented in Moraes et 
al. (2006) suggest that these mountains act as a filter to sponge colonization of Trindade Island, which appears to be comparatively poor (23 species known up to now) in contrast to localities closer to the continent (over 100 species registered; Appendix). It seems premature to consider this a well-established general knowledge, because the taxonomic inventory of the sponge fauna of Trindade Island 'is still in its early steps. But, on the other hand, the impoverished insular fauna, when contrasted to localities on the continental shelf or closer to it, is the expected outcome of Island Biogeography Theory and a likely consequence of the comparatively smaller area and large distance of the island from the mainland.

\section{ACKNOWLEDGEMENTS}

A.D. Pimenta (Museu Nacional/UFRJ) is thanked for the identification of the siliquariid gastropod endobiotic in $Y$. sphaeroidocladus, the possibility of this not being a vermetid, as we first thought, having been brought to our attention by L.R. Simone (Museu de Zoologia, University of São Paulo). V. Shimabukuru and A.C. Marques are thanked for the identification of the sertulariid epibiotic on the same sponge. C.R.R. Ventura (Museu Nacional/UFRJ) is thanked for the identification of the ophiuroid epibiotic on A. alcicornis, and G. Muricy for granting access to an unpublished catalogue of Brazilian sponges, co-authored by EH, where most of the effort to compile lists of published sponge records for Brazilian states has already been undertaken. D.A. Lopes and M.V. de Oliveira are thanked for sorting out sponge samples in REVIZEE Central V and VI oceanographic cruises. Elivaldo de Lima and Amanda Garcez da Veiga are thanked for SEM operation at the Center for Scanning Electron Microscopy of the Departamento de Invertebrados (Museu Nacional/UFRJ). The establishment of this Center was achieved thanks to a grant from CENPES/ PETROBRAS, and is part of the company's Thematic Network for Marine Environmental Monitoring. CNPq and FAPERJ provided grants and/or fellowships to $\mathrm{EH}$ which are greatly acknowledged. JNT graduated in Biological Sciences with Centro Universitário de Vila Velha (Vila Velha, ES, Brazil).

\section{LITERATURE CITED}

Boury-Esnault, N. 1973. Campagne de la 'Calypso' au large des côtes Atlantiques de L'Amérique du Sud (1961-1962). I. Résultats scientifiques des Campagnes de la 'Calypso' 10 (29): 263-295.

Boury-Esnault, N.; E. Hajdu; M. Klautau; M.R. Custódio \& R. Borojevic. 1994. The value of cytological criteria in distinguishing sponges at the species level: the example of the genus Polymastia. Canadian Journal of Zoology 72: 795-804.

Borojevic, R. \& S. Peixinho. 1976. Eponges calcaires du NordNord-Est du Brésil. Bulletin du Muséum national d'Histoire naturelle (3, A) 402: 987-1036.
Gómez, P. 2006. Yucatania clavus, new genus and species of the family Thrombidae (Porifera: Demospongiae: Astrophorida) from the continental shelf off Yucatan, Mexico. Proceedings of the Biological Society of Washington 119 (3): 339-345.

Hajdu, E. \& N. Boury-Esnault. 1991. Marine Porifera of Cabo Frio (Rio de Janeiro - Brazil). The family Mycalidae Lundbeck, 1905, with the description of a new species. Revista Brasileira de Biologia 51(3): 503-513.

Hajdu, E. \& R. Desqueyroux-Faúndez. 1994. A synopsis of South American Mvcale (Mycale) (Poecilosclerida, Demospongiae), with the description of three new species and a preliminary cladistic analysis of Mycalidae. Revue Suisse de Zoologie 101 (3): 563-600.

Hajdu, E. \& D.A. Lopes. 2007. Checklist of Brazilian deep-sea sponges, p. 353-359. In: M.R. Custódio; G. LôBo-Hajdu; E. Hajdu \& G. Muricy (Eds). Porifera Research: Biodiversity, Innovation \& Sustainability. Rio de Janeiro, Museu Nacional, Série Livros 28, VI+684p.

Hajdu, E.; R. Desqueyroux-Faúndez \& P. Willenz. 2006. Clathria (Cornulotrocha) rosetafiordica sp. nov. from a south-east Pacific fjord (Chilean Patagonia) (Microcionidae: Poecilosclerida: Demospongiae: Porifera). Journal of the Marine Biological Association of the United Kingdom 86: 957-961. doi:10.1017/S0025315406013920.

Hajdu, E.; G. Muricy; M. Custodio; C. Russo \& S. Peixinho. 1992. Geodia corticostylifera (Demospongiae, Porifera), new astrophorid from the Brazilian coast (Southwestern Atlantic). Bulletin of Marine Science 51: 204-217.

Hajdu, E.; S. Zea; M. Kielman \& S. Peixinho. 1995. Mycale escarlatei n. sp. and Mycale unguifera n. sp. (Demospongiae) from the tropical-western Atlantic. Beaufortia 45 (1): 1-16.

Hartman, W.D. \& R. Hubbard. 1999. A new species of Thrombus (Porifera: Demospongiae: Astrophorida) from Trinidad, West Indies. Bulletin of Marine Science 64 (1): 1-8.

Hechtel, G.J. 1976. Zoogeography of Brazilian marine Demospongiae, p. 237-260. In: F.W. HARRISON \& R.R. COWDEN (Eds). Aspects of sponge biology. New York, Academic, 367p.

Laborel, J. 1967. A revised list of Brazilian Scleractinia corals and description of a new species. Postilla 107: 1-14.

LaVRado, H.P. 2006. Caracterização do ambiente e da comunidade bentônica, p. 19-64. In: H.P. Lavrado \& B.L. Ignácio (Eds). Biodiversidade bentônica da região central da Zona Econômica Exclusiva brasileira. Rio de Janeiro, Museu Nacional, Série Livros 18, 389p.

Lopes, D.A.; E. Hajdu \& H.M. Reiswig. 2005. Redescription of two Hexactinosida (Porifera, Hexactinellida) from the southwestern Atlantic, collected by Programme REVIZEE. Zootaxa 1066: 43-56.

Menegola, C.; J.C.C. Fernandez; A. Lage \& S. Peixinho. 2009. Two new records of Thrombidae Sollas, 1888 (Porifera, Demospongiae, Astrophorida) from Brazil, Southwestern Atlantic, p. 1622-1631. In: XIII Congreso Latinoamericano de Ciencias del Mar Colacmar. Havana, Publicaciones del XIII Colacmar. 
Menshenina, L.L.; K.R. Tabachnick; D.A. Lopes \& E. Hajdu. 2007. Revision of Calycosoma Schulze, 1899 and finding of Lophocalyx Schulze, 1887 (six new species) in the Atlantic Ocean (Hexactinellida, Rossellidae), p. 449-465. In: M.R. Custódio; G. Lôbo-Hajdu; E. Hajdu \& G. Muricy (Eds). Porifera Research: Biodiversity, Innovation \& Sustainability. Rio de Janeiro, Museu Nacional, Série Livros 28, VI+684p.

Moraes, F. \& G. Muricy. 2007. A new species of Erylus (Geodiidae, Demospongiae) from Brazilian oceanic islands, p. 467-475. In: M.R. Custódio; G. Lôbo-Hajdu; E. Hajdu \& G. Muricy (Eds). Porifera Research: Biodiversity, Innovation \& Sustainability. Rio de Janeiro, Museu Nacional, Série Livros 28, VI+684p.

Moraes, F.; M. Ventura; M. Klautau; E. Hajdu \& G. Muricy. 2006. Biodiversidade de esponjas das ilhas oceânicas brasileiras, p. 147-177. In: R.J.V. Alves \& J.W.A. Castro (Orgs). Ilhas Oceânicas Brasileiras, da Pesquisa ao Manejo. Brasília, Ministério do Meio Ambiente, 298p.

Muricy, G. \& E. Hajdu. 2006. Porifera Brasilis. Rio de Janeiro, Museu Nacional, Série Livros 17, 104p.

Muricy, G. \& S.M. Ribeiro. 1999. Shallow-water Haplosclerida (Porifera, Demospongiae) from Rio de Janeiro state, Brazil (Southwestern Atlantic). Beaufortia 49 (6): 47-60.

Muricy, G.; E. Hajdu; M.V. Oliveira; A.S. Heim; R.N. Costa; D.A. Lopes; M. Melão; P.R.D. Rodriguez; R. Silvano; L.C. Monteiro \& C. Santos. 2007. Filo Porifera, p. 23-57. In: H.P. Lavrado \& M.S. VIANA (Eds). Atlas de invertebrados marinhos da região central da Zona Econômica Exclusiva brasileira. Rio de Janeiro, Museu Nacional, Série Livros 25, 258p.

Muricy, G.; C.P. Santos; D. Baptista; D.A. Lopes; D. Pagnoncelli; L. Monteiro; M.V. Oliveira; M.C.F. Moreira; M.S. Carvalho; M. Melão; M. Klautau; P.R. Dominguez; R.N. Costa; R.G. Silvano; S. Schwientek; S.M. Ribeiro; U. Pinheiro \& E. Hajdu. 2006. Filo Porifera, p. 109-145. In: H.P. LAVRADo \& B.L. IgNÁcIO (Eds). Biodiversidade bentônica da região central da Zona Econômica Exclusiva brasileira. Rio de Janeiro, Museu Nacional, Série Livros 18, 389p.

Muricy, G.; E.L. Esteves; F. Moraes; J.P. Santos; S.M. Silva; E.V.R. Almeida; M. Klautau \& E. Lanna. 2008. Biodiversidade Marinha da Bacia Potiguar: Porifera. Rio de Janeiro, Museu Nacional, Série Livros 29, 156 p.

PaLACIO, F.J. 1982. Revisión zoogeográfica marina del Sur del Brasil. Boletim do Instituto Oceanográfico, São Paulo 31: 69-92.
Pinheiro, U.S.; E. Hajdu \& M.R. Custódio. 2007. Aplysina Nardo (Porifera, Verongida, Aplysinidae) from the Brazilian coast with description of eight new species. Zootaxa 1609: 1-51.

RidLEy, S.O. 1881. XI. Spongida. Horny and Siliceous Sponges of Magellan Straits, S.W. Chili, and Atlantic off S.W. Brazil. In: A. Gunther (Ed.). Account of the Zoological Collections made during the Survey of H.M.S. 'Alert' in the Straits of Magellan and on the Coast of Patagonia. Proceedings of the Zoological Society of London 49 (1): 107-137, 140-141.

Rodriguez, P.R.D. \& G. Muricy. 2007. A new species of Cinachyra (Demospongiae: Tetillidae) collected by Project REVIZEE off Espírito Santo State, SE Brazil, p. 547-553. In: M.R. Custódio; G. Lôbo-Hajdu; E. Hajdu \& G. Muricy (Eds). Porifera Research: Biodiversity, Innovation \& Sustainability. Rio de Janeiro, Museu Nacional, Série Livros 28, VI+684p.

Solé-Cava, A.M.; A. Kelecom \& G.J. Kannengiesser. 1981. Study of some sponges (Porifera, Demospongiae) from the infralitoral of Guarapari, Espírito Santo, Brazil. Iheringia, Série Zoologia, 60: 125-150.

Tabachnick, K.R.; L. Menshenina; D.A. Lopes \& E. Hajdu. 2009. Two new Hyalonema species (Hyalonematidae: Amphidiscosida) from eastern and south-eastern Brazil, and further Hexactinellida (Porifera) collected from seamounts off south-eastern Brazil by the RV 'Marion Dufresne' MD55 expedition. Journal of the Marine Biological Association of the United Kingdom 89 (6): 1243-1259.

Van Soest, R.W.M. 1984. Marine sponges from Curacao and other Caribbean localities. Part 3. Poecilosclerida. Studies on the Fauna of Curacao and other Caribbean Islands 66 (199): 1-167.

van Soest, R.W.M.; N. Boury-Esnault; J.N.A. Hooper; K. Rützler; N.J. de Voogd; B. Alvarez; E. Hajdu; A.B. Pisera; J. Vacelet; R. Manconi; C. Schoenberg; D. Janussen; K.R. Tabachnick \& M. Klautau. 2009. World Porifera Database. Available online at: http://www.marinespecies.org/porifera [Accessed: 13/ VIII/2010]

Vieira, W.F.; B. Cosme \& E. Hajdu. 2010. Three new Erylus (Demospongiae, Astrophorida, Geodiidae) from the Almirante Saldanha Seamount (off SE Brazil), with further data for a tabular review of worldwide species and comments on Brazilian seamount sponges. Marine Biology Research 6: 437-460. doi: 10.1080/17451000903334728.

Submitted: 16.VIII.2010; Accepted: 25.III.2011.

Editorial responsibility: Rosana M. da Rocha 
Appendix. Alphabetical list of sponges hitherto recorded from off Espírito Santo, with indication of the bibliographic source of the record. Species are listed for each Class in separate, and respecting alphabetical order. The current classification scheme for each of these species can be obtained from VAN SOEST et al. (2009). Publications used for this compilation are numbered, and these numbers are added next to the species name. (1) Borojevic \& Peixinho (1976), (2) Boury-Esnault (1973), (3) Boury-Esnault et al. (1994), (4) Hajdu (unpub. data), (5) Hajdu \& Boury-Esnault (1991), (6) Hajdu \& Desqueyroux-Faúndez (1994), (7) Hajdu \& Lopes (2007), (8) Hajdu et al. (1992), (9) Hechtel (1976), (10) Lopes et al. (2005), (11) Menshenina et al. (2007), (12) Moraes \& Muricy (2007), (13) Moraes et al. (2006), (14-16) Muricy et al. $\left(2006^{14}, 2007^{15}, 2008^{16}\right)$, (17) Muricy \& Hajdu (2006), (18) Muricy \& Ribeiro (1999), (19) Ridley (1881), (20) Solé-Cava et al. (1981), (21) TABACHNICK et al. (2009), (22) VIEIRA et al. (2010) and (23) present study. * Species with known distribution ranges reaching the Central Western Atlantic.

\section{Calcarea}

Clathrina atlantica (Thacker, 1908) ${ }^{1}$

Clathrina reticulum (Schmidt, 1862)

Clathrina sp. nov. ${ }^{13}$

Leucaltis Clathria Haeckel, $1872^{1}$

Leucandra armata (Urban, 1908) ${ }^{1}$

Leucandra barbata (Duchassaing \& Michelotti, 1864) ${ }^{1}$

Leucandra caminus var. crassior Ridley, 18811,19

Leucandra rudifera Poléjaeff, $1883^{13}$

Leucetta floridana (Haeckel, 1872) ${ }^{1}$

Paraleucilla sp. nov. ${ }^{13}$

Sycettusa pelagica (Ridley, 1881) ${ }^{19}$

Vosmaeropsis sericatum (Ridley, 1881) ${ }^{19}$

Demospongiae

Aaptos sp. ${ }^{7,14}$

*Acarnus nicoleae van Soest, Hooper \& Hiemstra, $1991^{14}$

Acarnus toxeata Boury-Esnault, $1973^{14}$

Acarnus sp. ${ }^{14}$

*Agelas clathrodes (Schmidt, 1870)7, 14, 15

*Agelas conifera (Schmidt, 1870) 14, 22

*Agelas dispar Duchassaing \& Michelotti, 18642, 14, 22

*Agelas schmidti Wilson, 19027, 14, 15

Agelas sp.7, 14, 22

*Aiolochroia crassa (Hyatt, 1875)7, 14, 15, 22

Aiolochroia sp. ${ }^{14,} 22$

*Aka coralliphaga (Rützler, 1971) ${ }^{13}$

*Amphimedon viridis Duchassaing \& Michelotti, $1864{ }^{18}$

Aplysina alcicornis Pinheiro et al., 2007 23

Aplysina aff. cauliformis (Carter, 1882) ${ }^{14}$

*Aplysina cauliformis (Carter, 1882) 14, 15, 22

*Aplysina fulva (Pallas, 1766) ${ }^{14,15,22}$

Aplysina cf. fulva ${ }^{7}, 14$

*Aplysina lacunosa (Lamarck, 1814)7, 14, 15

Aplysina sp. 7, 14, 22

Axinella sp.

Cacospongia sp. ${ }^{13}$

Callyspongia sp. ${ }^{14}$

*Chalinula molitba (de Laubenfels, 1949) ${ }^{13}$

${ }^{*}$ Chondrilla nucula Schmidt, $1862^{13,14}$

Chondrosia sp. ${ }^{17}$

Cinachyra helena Rodriguez \& Muricy, 20077, 14, 22

Cinachyrella aff. kuekenthali (Uliczka, 1929) ${ }^{14,22}$
*Cinachyrella kuekenthali (Uliczka, 1929) $)^{14,15,22}$

Clathria sp. ${ }^{13,14}$

${ }^{*}$ Cliona celata complex Grant, $1926^{17}$

*Cliona varians (Duchassaing \& Michelotti, 1864) ${ }^{16}$

Cliona sp. ${ }^{14}$

Craniella sp. ${ }^{7}$

Crella sp. ${ }^{13}$

*Cyamon vickersi (Bowerbank, 1866) ${ }^{2}$ [as Timea agnani BouryEsnault, 1973]

Darwinella sp. ${ }^{14}$

Desmacella sp. ${ }^{14}$

*Diplastrella megastellata Hechtel, $1965^{14}$

Dragmacidon sp. ${ }^{14,22}$

Dragmaxia aff. undata Alvarez, van Soest \& Rützler, $1998^{14}$

Dysidea avara (Schmidt, 1862) 2

Dysidea sp. ${ }^{14}$

*Ectyoplasia ferox (Duchassaing \& Michelotti, 1864) ${ }^{14}$

Erylus almirante Vieira et al., $2010^{22}$

Erylus fluminense Vieira et al., $2010^{22}$

${ }^{*}$ Erylus formosus Sollas, $1886^{16}$

Erylus aff. formosus Sollas, $1886^{14}$

Erylus latens Moraes \& Muricy, $2007^{12}$

Erylus revizee Vieira et al., $2010^{22}$

Erylus sp. ${ }^{7,12,14}$

${ }^{*}$ Geodia corticostylifera Hajdu et al. 19928, 16, 17

${ }^{*}$ Geodia gibberosa Lamarck, 181516,17

Geodia glariosa (Sollas, 1886) ${ }^{16}$

Hippospongia sp. ${ }^{14}$

*Hyattella cavernosa (Pallas, 1766) ${ }^{14,15}$

*Ircinia felix (Duchassaing \& Michelotti, 1864) ${ }^{13}$

*Ircinia strobilina (Lamarck, 1816)9,13,15

Ircinia sp. ${ }^{14}$

Jaspis salvadori Boury-Esnault, $1973^{2}$

Monanchora aff. clathrata Carter, $1883^{14}$

Monanchora sp. ${ }^{14}$

*Mycale (Aegogropila) escarlatei Hajdu et al., $1995^{23}$

Mycale (Mycale) arenaria Hajdu \& Desqueyroux-Faúndez, 19944, 5, 6, 17, 20 Mycale sp. ${ }^{14}$

Oceanapia sp.7, 14, 22

Pachastrissa sp. ${ }^{22}$

Petromica sp. ${ }^{22}$

*Petrosia weinbergi van Soest, $1980^{13}$

Phorbas capixaba sp. nov. ${ }^{23}$ 
Phorbas sp. ${ }^{14}$

Plakina sp. ${ }^{7,14}$

Plakinastrella microspiculifera Moraes \& Muricy, 2003 ${ }^{13,16}$

Plakinastrella sp..$^{14,22}$

Polymastia janeirensis (Boury-Esnault, 1973) ${ }^{3}$

Polymastia sp. ${ }^{14}$

Rhabderemia sp. ${ }^{22}$

Spongia sp. ${ }^{14}$

Spongosorites sp. ${ }^{22}$

Stelletta anancora (Sollas, 1886) $)^{15}$

Stoeba sp. ${ }^{14}$

${ }^{*}$ Tedania ignis (Duchassaing \& Michelotti, 1864) ${ }^{16}$

Tedania sp. ${ }^{14}$

Tethytimea sp. ${ }^{14}$

Tetilla sp. ${ }^{14}$

Thoosa sp. ${ }^{14}$

Timea cumana Pulitzer-Finali, 1977 14,15

Timea sp. nov. ${ }^{14}$

${ }^{*}$ Topsentia ophiraphidites (de Laubenfels, 1934) ${ }^{13}$
Topsentia sp. ${ }^{14}$

*Verongula gigantea (Hyatt, 1875) 13, 14, 15

Xestospongia sp. ${ }^{22}$

*Yucatania sphaeroidocladus (Hartman \& Hubbard, 1999) ${ }^{14,23}$

Hexactinellida

Aphrocallistes aff. beatrix Gray, $1858^{21}$

Aphrocallistes beatrix Gray, 18587, 10, 14

Dactylocalyx pumiceus Stuchbury, $1848^{22}$

Dactylocalyx aff. subglobosus Gray, $1867^{21}$

Dactylocalyx sp. ${ }^{21}$

Euplectella suberea Thomson, $1877^{21}$

Farrea sp. ${ }^{21}$

Hyalonema (Cyliconema) conqueror Tabachnick et al., $2009^{21}$

Hyalonema (Cyliconema) sp. ${ }^{21}$

Hyalonema (Prionema) dufresnei Tabachnick et al., $2009^{21}$

Hyalonema (Prionema) sp. ${ }^{21}$

Lophocalyx brasiliensis Menshenina et al., $2007^{11}$

Sarostegia aff. oculata Topsent, $1904^{21}$ 